Article

\title{
Intrinsic Workforce Diversity and Construction Worker Productivity in Pakistan: Impact of Employee Age and Industry Experience
}

\author{
Ahsen Maqsoom ${ }^{1}\left(\mathbb{D}\right.$, Hasnain Mubbasit ${ }^{1}$, Muwaffaq Alqurashi ${ }^{2}{ }^{(\mathbb{D}}$, Iram Shaheen ${ }^{3}$, Wesam Salah Alaloul ${ }^{4, *}{ }^{(\mathbb{D}}$,

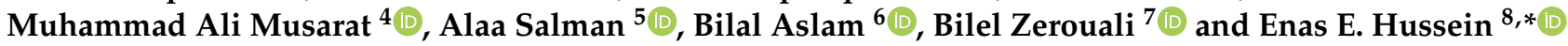 \\ 1 Department of Civil Engineering, COMSATS University Islamabad Wah Campus, Wah Cantt 47040, Pakistan; \\ ahsen.maqsoom@ciitwah.edu.pk (A.M.); HasnainM_11@hotmail.com (H.M.) \\ 2 Department of Civil Engineering, College of Engineering, Taif University, P.O. Box 11099, Taif 21944, Saudi Arabia; \\ m.gourashi@tu.edu.sa \\ 3 Department of Management Sciences, COMSATS University Islamabad Wah Campus, Wah Cantt 47040, \\ Pakistan; iramshaheen8765@gmail.com \\ 4 Department of Civil and Environmental Engineering, Universiti Teknologi PETRONAS, Seri Iskandar 32610, \\ Perak, Malaysia; muhammad_19000316@utp.edu.my \\ 5 Department of Civil and Construction Engineering, Imam Abdulrahman Bin Faisal University, \\ Dammam 34212, Saudi Arabia; akalobaidi@iau.edu.sa \\ 6 Department of Earth Sciences, Quaid-i-Azam University, Islamabad 45320, Pakistan; bilalaslam45@gmail.com \\ 7 Vegetable Chemistry-Water-Energy Research Laboratory, Faculty of Civil Engineering and Architecture, \\ Hassiba Benbouali, University of Chlef, B.P. 78C, Ouled Fares, Chlef 02180, Algeria; b.zerouali@univ-chlef.dz \\ 8 National Water Research Center, P.O. Box 74, Shubra El-Kheima 13411, Egypt \\ * Correspondence: wesam.alaloul@utp.edu.my (W.S.A.); enas_el-sayed@nwrc.gov.eg (E.E.H.)
}

Citation: Maqsoom, A.; Mubbasit, H.; Alqurashi, M.; Shaheen, I.; Alaloul, W.S.; Musarat, M.A.; Salman, A.; Aslam, B.; Zerouali, B.; Hussein, E.E. Intrinsic Workforce Diversity and Construction Worker Productivity in Pakistan: Impact of Employee Age and Industry Experience. Sustainability 2022, 14, 232. https://doi.org/ $10.3390 /$ su14010232

Academic Editor: Elena

Cristina Rada

Received: 7 October 2021

Accepted: 22 December 2021

Published: 27 December 2021

Publisher's Note: MDPI stays neutral with regard to jurisdictional claims in published maps and institutional affiliations.

Copyright: (C) 2021 by the authors. Licensee MDPI, Basel, Switzerland. This article is an open access article distributed under the terms and conditions of the Creative Commons Attribution (CC BY) license (https:// creativecommons.org/licenses/by/ $4.0 /)$.
Abstract: Worker productivity is critical within construction projects as it is the measure of the rate at which work is performed and, more importantly, helps to know how to motivate them to perform at high levels. This research aimed to examine the impact of employee age and industry experience on the intrinsic workforce diversity factors influencing construction worker productivity. Sieving through the previous research and models and theories of analysis, the intrinsic workforce diversity was modeled into the following set of factors, i.e., income, motivation, psychosocial factors, and technical skills. The data were collected by means of a questionnaire survey and examined for the employees having different ages and experiences using the Mann-Whitney $U$ test through SPSS. The results show that employees of varied ages do not concur over motivation-, psychosocial, and technical skills-related workforce diversity factors, whereas employees of varied industrial experiences are in disagreement over some income and motivation related workforce diversity factors. In order to overcome intrinsic workforce diversity, firm support is direly needed for old and mature employees in terms of financial incentives leading to motivation, less supervised scheduling, opportunities for firm advancement, and reporting back every time work is completed. Furthermore, support is required for young employees who are more susceptible due to psychosocial stresses like unevenly distributed work, communication gaps, and technical skills like knowledge of technological equipment and advancement in construction technology which has reduced the skills of workers.

Keywords: workforce diversity; technical skills; motivation; psychosocial; construction worker; productivity

\section{Introduction}

With escalating globalization, managing diversity in organizations has turned into a necessarily important issue [1]. There is a broad consensus among scholars about the need to keenly deal with workforce diversity in firms and discover the advantages and drawbacks for the various factors involved in diversity [1-3]. Diversity literature inspects how differences among employees affect team performance [4]. The major effects of those 
differences yield mixed empirical results on different performance indicators. To make their effects on the performance better understandable, researchers propose a combined analysis of diversity, organizational practices, and different task characteristics.

According to Roberge and Van Dick [5], the foremost vital quality of any organization is a heterogeneous workforce that not only helps mitigate problems, but also supplies different and creative ideas with a competitive advantage to the organization, but diversity can also bring negative outcomes. It has often been acknowledged that heterogeneity can reduce intragroup coherency and lead to disagreements and misunderstandings which, in turn, can lower employee satisfaction, citizenship behaviors, and increase turnover [6], whereas earlier consensus showed that to have strong positive associations with the perceived group and group satisfaction, openness to linguistic, value, and information diversity is essential. Within a team, a homogenous workforce can improve the workflow because there are no social or cultural barriers [7]. In order to manage the growing diversity of the workforce, organizations need to implement systems and practices so that the potential advantages of diversity are maximized and the potential disadvantages are minimized. The influence of demographic differences on work performance needs to be categorized. Particularly on the group level, positive impacts of diversity were shown by Guillaume and Dawson [8] and by Downey and van der Werff [9]. Workforce being a dominant resource in construction, it can be argued that productivity of the construction industry around the globe critically relies on human performance [10,11].

Pakistan is a growing economy with construction being the second largest sector after agriculture. With the China-Pakistan Economic Corridor (CPEC) initiative, workers from both of these demographically diverse countries get employed to work together with national and multinational firms [12]. According to the Planning Commission of Pakistan, the CPEC has employed 30,000 Pakistani engineers and laborers under their Early Harvest projects. These recent steps have led workers from different areas to work and learn together with more interest than ever before. Moreover, teams with diverse strength have subjugated less diverse groups as far as creativity and contentment is concerned [1]. Different perspective about the advantages and disadvantages of diversity in an organization results in different approaches and management ways $[13,14]$. Therefore, construction worker productivity is a fundamental productivity index of the assignment of manpower to an absolutely specific task.

A few contributions were made by previous studies to the understanding of the effect of workforce diversity factors on employee performance; however, these studies are inconclusive in various dimensions [15-17]. Ibrahim and Brobbey [18] found out that younger workers need more motivation to do an assigned task than older workers; hence, motivation is the most influential factor for employee performance. Van Dalen and Henkens [19] worked on the impact of factors that cause psychosocial stresses and found that employees over the age of 40 face different problems, e.g., tough weather conditions, workspace atmosphere, and long working hours in a firm. Alsuwaiyel [20] examined the consequences of advancement in technology towards unskilled employees in the time to come. Further, he explained the need for old and mature employees to enhance their skill-set with this ongoing technical advancement in order to surpass young age and inexperienced employees. A study held in Belgium proved that the majority of firms in the developing countries have well-documented labor force, overall size, capital used, and productivity, but there is no information on the classification of workforce characteristics that would allow for a more refined breakdown of diversity-defining factors [21].

One of the important issues raised by the ageing society is its impact on productivity, adaptation, and innovation [22]. Age diversity has a definitive negative dependence on performance, but researchers have also expressed that younger and older employees must intermingle to form a coherent and efficient corporate culture and achieve better firm performance. There is a need for different approaches to be developed to study age-based performance evaluation [23]. On the other hand, a meta-analysis by Quinones and Ford [24] revealed a positive relationship between employee experience and performance [19]. 
A few studies have been able to identify the behavior of experienced and inexperienced employees. By far, no study has examined the association of workforce diversity factors, i.e., income, motivation, psychosocial factors, and technical skills, with the workers' productivity with respect to varied age and experience. This study investigated the impact of workforce diversity factors on worker productivity in the construction industry of Pakistan. Various influencing factors related to income, motivation, psychosocial factors, and technical skills were inspected in this study. Further, the impact of these factors in accordance with age and experience of the employees was analyzed. The outcome of this study will immensely contribute to the literature on labor productivity, where there is a scarcity of literature related to the association between workforce diversity factors, age and experience.

\section{Theoretical Framework}

The term "diversity" refers to the personnel attributes distributed among codependent members of a work unit [4]. The assorted outcomes of past theories conjointly help to point out the distinction between the theoretical background and the current research.

The job demands-resources (JD-R) model emphasizes the importance of technical skills and psychosocial stress in a workforce. Karasek Jr. [25] proposed that although pressures (both psychological and social) and job demands have an influence on stresses, these demands are not the sole contributors to these stresses. Rather, the amount of stress workers experience in their work majorly depends upon their control over the demands. At the heart of the JD-R model is the assumption that although every occupation may have its own causes of employee well-being, these factors can be classified into two general categories (i.e., job demands and job resources); it thus constitutes an overarching model that may be applied to various occupational settings irrespective of the particular demands and resources involved. In the field of construction, employees from developing countries seem to be losing that control over such demands in sight of comparing themselves with employees in the developed countries who have better technical skills. Factors such as short deadlines, high volume of work, no learning opportunities, etc. are also negative demands that bring down the morale of employees. In this case, the JD-R model postulates job positives/resources that are provided to workers to increase autonomy, organizational rules that strengthen employees, coaching/mentoring, and constructive feedback to generate knowledge/skills in their working environment. JD-R also suggests personal resources such as self-efficacy, optimism, etc. These resources act as a buffer between team members and the demands of their roles.

The equity theory [26] postulates a worker's motivation is a measure of his/her input into the job against the output received from it. The higher the reward, the greater the worker's motivation. Regarding the equity theory, workers who perceive getting better output from their jobs than what they think they put into it feel job satisfaction. These certain aspects vary with every worker's approach toward satisfaction. Tasks that are well-understood and clarified bring up satisfaction since a clear role helps the workforce to be involved and committed. Further, the author identified five characteristics that impact the psychological and motivational state of a worker, namely autonomy, identity and significance of the task, income, and feedback. Further, workers compare their input/output ratio with other workers and if it is found to be fair, it leads to job satisfaction, receiving rewards and motivation. The theory argues that managers should seek to find a balanced way between the inputs that an employee gives and the outputs received. The conceptual framework incorporates technical skills-related and psychosocial workforce diversity factors using the JD-R model. The technical skills related to workforce diversity factors as well as psychosocial factors are examined using the JD-R model, whereas income and motivation related to workforce diversity factors are examined using the equity theory as shown in Table 1. 
Table 1. Usage of theoretical models in the conceptual framework of the study.

\begin{tabular}{ccc}
\hline Theory/Models & Key Components for Diversity & Usage and Framework \\
\hline Job demands-resources model [25] & $\begin{array}{c}\text { Good job positives, e.g., } \\
\text { (a) leadership engagement, } \\
\text { (b) learning opportunities/skills for } \\
\text { advancement, and (c) autonomy, } \\
\text { can offset effects of extreme job } \\
\text { demands and encourage } \\
\text { motivation and engagement }\end{array}$ & $\begin{array}{c}\text { Technical skills, } \\
\text { psychosocial factors }\end{array}$ \\
\hline $\begin{array}{c}\text { Subtle and equitable input and } \\
\text { output factors affect each } \\
\text { individual's assessment and } \\
\text { perception of their work. } \\
\text { Dimensions include: (a) personal } \\
\text { efforts/satisfaction, (b) rewards } \\
\text { (salary, bonuses), and (c) referent to } \\
\text { being optimistic. }\end{array}$ & Income, motivation \\
\hline
\end{tabular}

\section{Workforce Diversity Factors Influencing Worker Productivity}

In one stream, there are scholars disputing that a diverse workforce holds a possible market advantage for an organization's success [27-29]. On the other hand, Lauretta McLeod and Lobel [30] stress that a diverse workforce helps in developing cohesion among ideas, turning out to be a success in the end. There are other authors whose position lies within the middle of those flows [31]. However, there seems to be an agreement that if diversity is controlled well, it may enhance productivity, and if unnoticed, it may reduce productivity. Structuring the previous theories to more refined factors, and through the literature support, workforce diversity is classified into the following dimensions: income, motivation, psychosocial factors, and technical skills.

Income has become a subject of serious debate about individuals' economics in the 21st century [32]. Recent developments, such as globalization, have led to vast competition. In order to face this stern competition, firms are continuously looking for ways to improve productivity of their workforce which cannot be achieved without job satisfaction of the working class. Incentives and profit distribution schemes are very common nowadays. In order to handle the problem, a monetary motivation scheme seems to be helpful for both young and old employees [33]. Official labor force statistics derived from administrative data, such as business or taxation records, does not provide a complete picture of trends in the labor market. In lower economic sectors, irregular microdata surveys could be used to have a check upon the work demands and wage policies in that region [34]. Employees with positive attention seem to be much satisfied with the pay relative to people with negative affectivity. Spies [35] studied the differences between the 26 factors of job satisfaction concluding income and the treatment by the parent company of the employees are triggering aspects of the employees' productivity.

Coming to the second factor, motivation is delineated as a force in a person responsible for the meticulousness of efforts spent at work [36]. According to Hofstede [37], managers must verify that the job crew is united and motivated inside the organization through rewards to confirm their continuous commitment. It follows from the top that employment motivation serves two essential purposes: to ensure productivity inside the worksite and list down employees' unity and loyalty through rewards, in particular, for those efforts which will result in higher productivity [38]. It has been observed that young employees need more motivation for their performance as compared to old employees [18]. Clear opportunities for career advancement are an especially powerful employee motivator. Moreover, the impact of job satisfaction and organizational commitment on the performance of employees is more in young employees as compared to old employees.

Stresses causing weak organizational commitment, job dissatisfaction, and demotivation in employees are mentioned as psychosocial stresses. Psychosocial factors include the way work is carried out, i.e., deadlines, workload, work methods, and the context in which work occurs, including relationships and interactions with managers, supervisors, coworkers, and clients or customers [39]. Their study revealed that the impact of job satisfaction, 
motivation, and organizational commitment on the performance of employees is higher on younger employees as compared to older employees. Another study revealed that psychosocial factors comprising lack of training programs and career mentoring greatly influence the performance of young employees as compared to old employees [40]. Psychological and social stresses have been found to be the most influential factors in carrying out tasks individually and in a group so far [41]. Work discipline, health and safety conditions, work satisfaction, creating competition, relationships with workmates, giving responsibility, sharing problems and their results, social activity opportunities, cultural differences, worker participation in decision-making, distance from home, and distance from population centers have been found to be the key attributes towards psychosocial effects [42-44].

There is ample research evidence suggesting technical skills as a significant factor affecting productivity in the construction industry [45]. For example, Rojas and Aramvareekul [46] reported that skills management and manpower issues are areas of the greatest potential of affecting productivity. Focused on the needs as a result of the globalized market and advantages of workforce diversity, the application of advanced technology has consequences for the relative labor demand [20]. It has been decreasing and will ultimately eliminate the ones without any efficient skills in the near future. Countries with weak economic development consequently exhibit lower levels of employee productivity [47]. A crucial challenge faced by more developed countries is how to make sure that the skills of both experienced and less experienced workers remain consistent throughout their careers. Firms' growth and workers' employability decelerate in the presence of skill gaps [48]. The need to upgrade skills applies not solely to the young generation in schools, universities, and training centers, but also to the current generation of workers following the opportunities to be created in the next two decades [49].

Therefore, a framework for learning the effective management of a diverse workforce and its influence on worker productivity in construction projects is still to be developed. A construction project may be a complicated body that may be planned as a system. However, like Harrison and Price [50] stressed, "people issues" are rather more problematic to unravel than technical problems within the short life of a project. Thus, for assuaging these issues, skills in managing workers are crucial. Therefore, sieving through the previous research and grasping theories, diversity has been carefully molded into the following intrinsic factors: income, motivation, psychosocial factors, and technical skills. The reason why these factors are needed to be studied for this research is that they emphasize the majority part of the difference, enhancements, changes, and processing of the environment that a worker experiences and goes through in their organization. As the JD-R model suggests, increasing work-related resources (autonomy, collaboration with colleagues, mentorship, skills advancement) and selecting staff with proactive personalities and a high level of motivation can increase work engagement and satisfactory employee performance outcomes [51]. The equity theory proposes that communication or status in an organization has an influence on the perceived fairness of pay. Work stresses have an effect on psychosocial strains, but the main pitcher to such strains is the demands that they have to contend with, but fair inputs (income, performance satisfaction, etc.) have a major impact on motivation and psychosocial factors [52]. They are further examined with respect to varied ages and experiences of employees in Pakistani construction contracting firms (CCFs) as shown in Figure 1. 


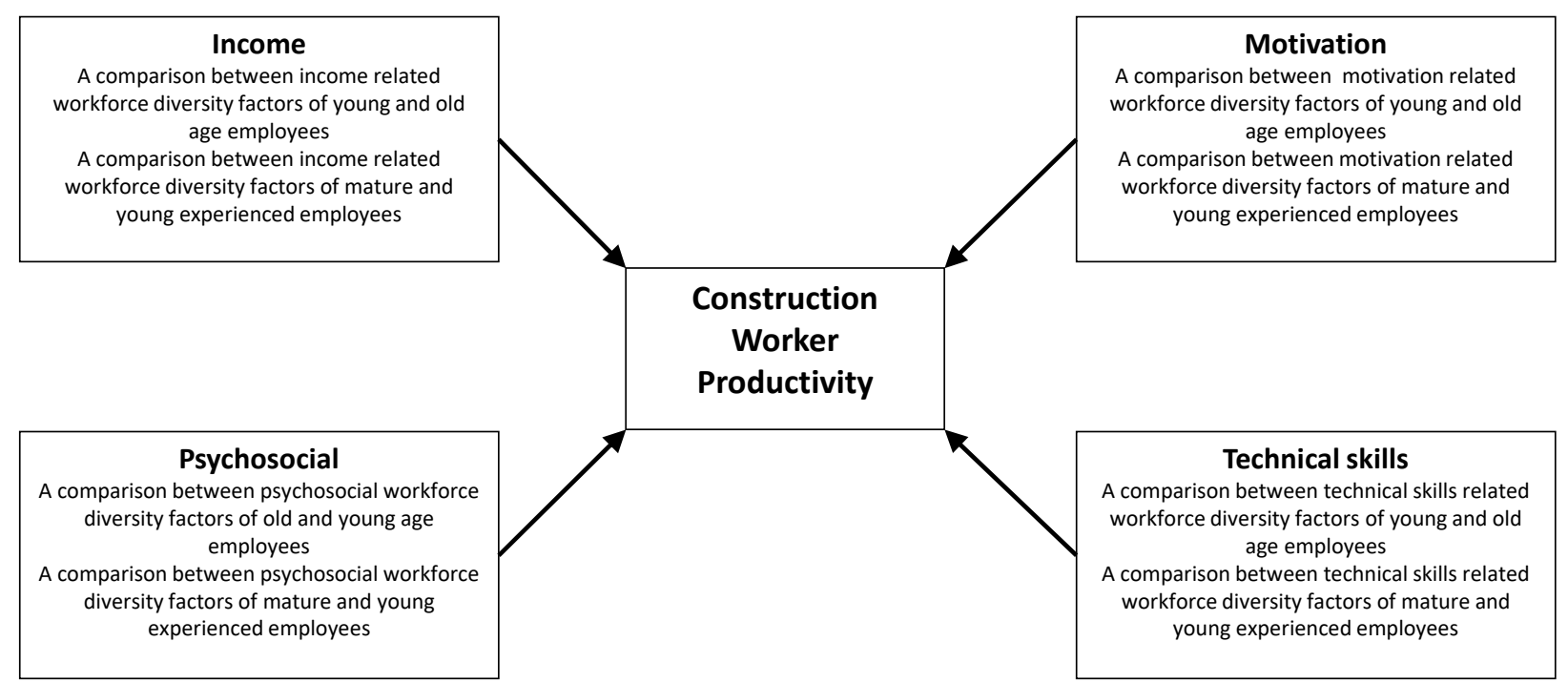

Figure 1. Conceptual framework.

\section{Methodology}

The computation of the literature reviewed above was used to develop the following research questions:

RQ1. What are the income-related workforce diversity factors that influence the productivity of Pakistani CCFs' workers of varied age and industry experience?

RQ2. What are the motivation-related workforce diversity factors that influence the productivity of Pakistani CCFs' workers of varied age and industry experience?

RQ3. What are the psychosocial workforce diversity factors that influence the productivity of Pakistani CCFs' workers of varied age and industrial experience?

RQ4. What are the technical skills-related workforce diversity factors that influence the productivity of Pakistani CCFs' workers of varied age and industrial experience?

In order to examine the above research questions, a questionnaire was sent to the firms to investigate intrinsic workforce diversity factors and their influence on worker productivity. Pilot testing of the questionnaire was carried out by interviewing eight construction executives. An improved questionnaire was developed by making some essential adjustments to the local industry context based on the recommendations and feedback received during the pilot phase. The questionnaire was divided into three sections incorporating 42 questions in total. The first section consisted of five questions related to the general background of the respondents and the firm. The second section consisted of five questions related to the productivity of employees [15]. The third section consisted of subsections related to four intrinsic factors. For this section, the scales were adapted from well-reputed previous studies, thus ensuring their validity. The first subsection was related to income, comprising eight questions [32], the second subsection consisted of eight questions related to motivation [38], the third subsection consisted of eight questions related to psychosocial stressors [41], and the last subsection related to technical skills consisted of eight questions [45].

To ensure validity of the questionnaire content, the contemporary approach developed by Schriesheim and Powers [53] was used. This approach was also used by Haynes and Weiser [54] in their research regarding surgical safety intervention. The respondents were asked to rate the intrinsic factors (income motivation, psychosocial factors, and technical skills) using a five-point Likert scale ranging from 1 (strongly disagree) to 5 (strongly agree). To reduce the common method variance (CMV) bias, it was conveyed to the correspondents that there were no right or wrong responses. Furthermore, they were assured of the confidentiality of the research so they could respond honestly [55]. 
Two hundred (200) questionnaires were sent to different engineers working at various construction sites in Pakistan where the profile of the respondents is shown in Table 2. It can be seen that most of the respondents were from firms who were involved in multiple specializations, i.e., involved in more than one business, e.g., civil as well as mechanical, followed by responses from civil and mechanical businesses. All the respondents were registered with the Pakistan Engineering Council (PEC), which is the statutory body responsible for the issuance of licenses to employees working in engineering businesses in Pakistan. Out of the total of 200 questionnaires that were sent to different construction engineers in Pakistan, 131 complete responses were returned, representing a response rate of 66 percent. After receiving the responses, the sample was divided into young vs. old and experienced vs. less experienced employee categories according to age and experience. In order to categorize employees according to their age, various classifications are used by different scholars in their studies, but no clear boundaries have been devised for the criteria. For instance, old employees are considered to be between the age of more than 35 and the age of more than 40 years [56], whereas the World Health Organization classifies old workers as those aged 45 or older. Similarly, the criteria used to distinguish experienced employees from less experienced employees were found to be different in different studies. Chung and Park [57] categorized employees having more than 15 years of work experience as experienced compared to less experienced employees.

Table 2. Profile of the survey respondents.

\begin{tabular}{|c|c|c|c|c|c|c|c|}
\hline Specializations & $\begin{array}{c}\text { Total Amount of } \\
\text { Construction } \\
\text { Workers }\end{array}$ & $\begin{array}{c}\text { Responses } \\
\text { Received (No.) }\end{array}$ & $\begin{array}{l}\text { Percentage to } \\
\text { the Total (\%) }\end{array}$ & $\begin{array}{l}\text { Young } \\
\text { Workers }\end{array}$ & $\begin{array}{c}\text { Old } \\
\text { Workers }\end{array}$ & $\begin{array}{c}\text { Less } \\
\text { Experienced } \\
\text { Workers }\end{array}$ & $\begin{array}{c}\text { Experienced } \\
\text { Workers }\end{array}$ \\
\hline Civil & 50 & 41 & 31 & 24 & 17 & 22 & 19 \\
\hline Petrochemical & 10 & 5 & 4 & 3 & 2 & 2 & 3 \\
\hline $\begin{array}{l}\text { Mechanical } \\
\text { and electrical }\end{array}$ & 40 & 31 & 23 & 17 & 14 & 18 & 13 \\
\hline $\begin{array}{c}\text { Multiple } \\
\text { specializations }\end{array}$ & 100 & 54 & 42 & 31 & 23 & 28 & 26 \\
\hline Total & 200 & 131 & 100 & 75 & 56 & 70 & 61 \\
\hline
\end{tabular}

In this study, old employees according to age were considered to be those older than 40 years and experienced employees were considered to be those with an experience of more than 10 years [56,58]. The data collected were then analyzed using the Statistical Package for Social Sciences (SPSS), version 21.0. The Shapiro-Wilk normality test was run to assess data normality. The data were found to be not normal, thus necessitating the need for a nonparametric test for the comparison between the studied groups. Hence, the nonparametric Mann-Whitney test was used to compare the scores of workers of different age (young, old) and experience (experienced, less experienced).

\section{Findings and Discussion}

In this research, only those variables were taken into consideration that recorded statistically significant differences between old vs. young workers and experienced vs. less experienced workers. The other variables having a significant two-tailed $p$-value more than 0.1 indicated no evidence to reject the null hypothesis. Therefore, the variables which did not record a statistically significant difference in the mean ranks were not documented.

The first stage of the analysis was related to the income-related diversity factors influencing the construction worker productivity. These factors were derived from the previous study based on wages and incremental policies of the workforce [33]. The results obtained indicate a few significant differences in the responses given by workers of varied ages and experiences for the income-related workforce diversity factors influencing the construction worker productivity as shown in Table 3. 
Table 3. Income-related workforce diversity factors influencing the construction worker productivity.

\begin{tabular}{ccccccc}
\hline Variables & $\begin{array}{c}\text { Old } \\
\text { Mean Rank }\end{array}$ & $\begin{array}{c}\text { Young } \\
\text { Mean Rank }\end{array}$ & $p$ & $\begin{array}{c}\text { Experienced } \\
\text { Mean Rank }\end{array}$ & $\begin{array}{c}\text { Less } \\
\text { Experienced } \\
\text { Mean Rank }\end{array}$ & $p$ \\
\hline Basic needs fulfillment & 63.27 & 69.57 & 0.331 & 65.39 & 65.63 & 0.968 \\
Work demand satisfaction & 64.19 & 67.89 & 0.531 & 69.53 & 60.80 & 0.124 \\
Satisfactory wage plan & 63.39 & 69.36 & 0.376 & 64.49 & 66.68 & 0.736 \\
Travel and daily allowances & 60.67 & 74.33 & $0.043 *$ & 60.00 & 71.92 & $0.066^{* *}$ \\
Worrying about the living & 62.46 & 71.05 & 0.196 & 59.69 & 72.28 & $0.048^{*}$ \\
for the next day & 64.77 & 66.83 & 0.759 & 65.89 & 65.05 & 0.896 \\
Annual increments & 63.59 & 68.99 & 0.413 & 61.32 & 70.38 & 0.152 \\
Wage deductions & 64.04 & 68.17 & 0.535 & 62.20 & 69.35 & 0.263 \\
Well-paid overtime & & & & &
\end{tabular}

Note: ${ }^{*}$ significant at $0.01,{ }^{* *}$ significant at 0.05 .

In terms of age, one variable is regarded more important by younger workers as compared to older workers, i.e., "travel and daily allowances" (mean rank $=74.33$ for younger employees and 60.67 for older employees with $p=0.043$ ).

Getting extra money for food and fuel is becoming a common routine for employees these days in the developing countries, especially Pakistan, due to high fluctuations in economics in the past decade. Younger employees do not seem to work enthusiastically and productively without such extra allowances compared to past decades, whereas older employees getting decent allowances impart a thought in younger ones. One of the foremost vital elements of running a prosperous business is keeping workers happy and providing them with enough incentives to maximize their productivity. If workers have solid health facilities, insurance plans in place, there is a higher probability that they are going to have a sustainable food supply, regular checkups and take preventative medical steps that ought to facilitate guaranteeing they do not take several sick days [59]. Providing worker advantages might cost a little, and the semipermanent benefits will greatly outweigh those costs and contribute to workers' overall success. Thus, such a business is poised to amass true professionals who are in it for a long time, facilitating a stable workforce.

In terms of experience, two variables are regarded more important by less experienced workers as compared to experienced workers, i.e., "travel and daily allowances" (mean rank $=71.92$ for less experienced employees and 60 for experienced employees with $p=0.066$ ) and "worrying about the living for the next day" (mean rank $=72.28$ for less experienced employees and 59.69 for experienced employees with $p=0.028$ ).

Incentives like food, fuel, transport, etc. act as a potential uplift in employees' motivation and, in short, productivity. These incentives definitely appear minor but their impact is quite prominent when analyzed. Experienced employees are always valued; many of them are given attractive salary packages, numerous incentives and securities that keep them motivated to do their work, whereas less experienced employees are not treated in the same way, but such incentives click with their minds [60]. There should be a revision in the policies of firms to add numerous incentives to the packages of their less experienced employees to keep the firm's progress high and the employees motivated.

Worrying about the living for the next day is not just a variable but a condition of many engineers and laborers working in the Pakistani construction industry. At par, $1000-1200$ Pak rupees is a wage rate a laborer gets, which is as low as $\$ 10-12$. Political or injustice strikes hit Pakistan more often, thus leading to the shutdown of businesses, and laborers that survive only on their daily wages do not have food to feed their families. Because of such terrible conditions, many less experienced employees related to the construction industry, primarily laborers, leave for countries abroad, mainly the UAE and other Gulf countries [61]. Wages and job securities of the firms there are far better than those of many of the firms in Pakistan [62]. Wage plans should be revised, and social security should be given to less experienced laborers to keep them motivated. It is not just a matter of keeping them working for their country, but also of the future of their country. If everyone keeps flying to other states like this, Pakistan will soon be deprived of a capable workforce.

The second stage of the analysis was related to the motivation-related diversity factors influencing the construction worker productivity. These factors were derived from 
the previous study based on the motivation of the workforce [38]. The results obtained indicate several significant differences in terms of age as well as experience of workers for the motivation-related workforce diversity factors influencing construction worker productivity as shown in Table 4.

Table 4. Motivation-related workforce diversity factors influencing the construction worker productivity.

\begin{tabular}{ccccccc}
\hline Variables & $\begin{array}{c}\text { Old } \\
\text { Mean Rank }\end{array}$ & $\begin{array}{c}\text { Young } \\
\text { Mean Rank }\end{array}$ & $p$ & $\begin{array}{c}\text { Experienced } \\
\text { Mean Rank }\end{array}$ & $\begin{array}{c}\text { Less } \\
\text { Experienced } \\
\text { Mean Rank }\end{array}$ & $p$ \\
\hline Monetary satisfaction & 66.42 & 63.82 & 0.673 & 69.80 & 60.48 & 0.116 \\
Financial incentives vs. & 67.80 & 61.29 & 0.310 & 71.11 & 58.95 & $0.048^{*}$ \\
nonfinancial incentives & 65.90 & 64.76 & 0.857 & 68.50 & 62.00 & 0.284 \\
Job security & 61.66 & 72.51 & $0.097 * *$ & 61.28 & 70.43 & 0.144 \\
Responsibility allocation & 69.77 & 57.70 & $0.067^{* *}$ & 70.45 & 59.73 & $0.089 * *$ \\
Self-scheduling and less & 67.29 & 62.24 & 0.428 & 71.39 & 58.63 & $0.037^{*}$ \\
supervised job decisions & 72.21 & 53.24 & $0.004^{*}$ & 71.31 & 58.73 & $0.047^{*}$ \\
Career advancement & 62.35 & 71.25 & 0.166 & 65.24 & 65.81 & 0.926 \\
Hatred for nosy & Informal relationships & & & & &
\end{tabular}

In terms of age, one variable is regarded more important by young workers than by old workers, i.e., "responsibility allocation" (mean rank $=72.51$ for younger employees and 61.66 for older employees with $p=0.097$ ). On the other hand, two other variables are regarded more important by older employees over younger employees, i.e., "selfscheduling and less supervised job decisions" (mean rank $=69.77$ for older employees and 57.7 with $p=0.067$ ) and "hatred for nosy" (mean rank $=72.21$ for older employees and 53.24 for younger employees with $p=0.004)$.

Responsibility gives a worker confidence over him-/herself, making them learn skills and team-leading qualities. Being a leader and in an authoritative position is always a desire for young employees [63]. In Pakistan, young employees have been given enough responsibilities that the majority of them seem very satisfied and eyeing forward to become more reliable employees. Seeking a satisfactory responsibility in a workplace is necessary for younger employees to keep them motivated towards work more than for the older ones who already have so many responsibilities that many of them are exhausted.

Coming to the second variable, older employees are found to prefer scheduling their work and making job-related decisions with minimum supervision as compared to younger employees [64]. Old workers feel pressed by excessive supervision and tight audits [65]. Over a decade ago, older workers crammed government positions, held places in top management, and the youngest worked on the face lines. Since then, the character of labor is, seemingly, rubbing elbows each day with those in different age groups. Today, Baby Boomers, several of whom have postponed their retirement, have realized themselves working under individuals young enough to be their grandchildren. The older worker/younger boss configuration will produce challenges. Completely different generations have distinctive views on everything, from workplace humor to communication vogue to figure ethics. Baby Boomers might feel awkward taking direction from younger bosses and younger bosses might feel awkward giving directions to them [66].

It is a common fact that an elder is older regardless of whether juniors surpass that person in the organizational race. Being an elder requires that person to be trusted and not just being ordered. Organizations that handle human resources must promote shared values, attitudes, and behaviors while reaching out in ways which are acceptable to every age group. Otherwise, hatred starts building up against young employees and bosses, resulting in an uncomfortable environment. It implies that older employees should be given respect in terms of supervision considering their age and experience, but quality should not be compromised no matter what [66].

In terms of experience, four variables are regarded more important by experienced workers than by less experienced workers, i.e., "financial incentives vs. nonfinancial incentives" (mean rank = 71.11 for experienced employees and 58.95 for less experienced employees with $p=0.048$ ), "self-scheduling and less supervised job decisions" (mean rank $=70.45$ 
for experienced employees and 59.73 for less experienced employees with $p=0.089$ ), "career advancement" (mean rank $=71.39$ for experienced employees and 58.73 for less experienced employees with $p=0.037$ ), and "hatred for nosy" (mean rank $=71.31$ for experienced employees and 58.73 for less experienced employees with $p=0.047$ ).

The analysis depicts that experienced employees emphasize financial incentives over other incentives. Living in a country of struggling economy and economic crises, monetary incentives have always played a productive role in terms of motivation of employees, especially when one has to work at a distant construction site. As an employee becomes more experienced, his/her knowledge becomes more groomed and their observation and decision-making powers become more precise and authentic. Apart from promoting them at a larger scale, incentives should be increased for their dedication to the firm as such a ripe experience cannot be bought with only salaries [67].

"Self-scheduling and less supervised job decisions" was the center of concern for the experienced employees. As the second important variable, it was noted that for an experienced employee, his/her seniority is higher than of those who have just come in the field regardless of how qualified the newcomers are. Therefore, the sense of interference and being supervised makes them resilient [66]. While managing employees who are more experienced than you, it is important to understand how and why they do things their way and only then start implementing changes. While "that is how we have always done" should never be used as an excuse, sometimes things are always done in a certain way for the reasons only an expert would know.

Regarding career advancement, it seems that mature employees got settled in their respective firms and made an identity after working all their lives and moving between different firms, and the firm they are working for now is somehow their final choice where they can see advancements for their career. Comparing to less experienced employees who are yet to touch the peak of their career, they are often seen unsatisfied with their jobs if they do not see advancements coming towards them as seen in the majority of the firms surveyed [68]. Therefore, they are in search of better jobs every day. The last variable, i.e., hatred for nosy, is also very commonly seen in firms with experienced employees. It will be wrong to say that experienced employees should be given full authority to do their work without being asked, but they should be given some authority that makes and keeps them well aware of their place in a workplace and makes them utilize their experience in much better ways [58].

The third stage of the analysis was related to the psychosocial stressors-related diversity factors influencing the construction worker productivity. These factors were derived from a previous study based on work-related psychosocial stressors [41]. The results obtained indicate several significant differences in the responses given by workers of varied ages; however, no significant difference was observed in the responses given by workers of varied experience for the psychosocial stressors-related workforce diversity factors influencing the construction worker productivity, as shown in Table 5.

In terms of age, two variables are regarded as more important by younger workers than by older workers, i.e., "uneven distribution of work" (mean rank $=73.52$ for younger employees and 61.11 for older employees with $p$-value $=0.061)$ and "workplace satisfaction" (mean rank $=73.7$ for younger employees and 61.01 for older employees with $p=0.049$ ), whereas, one variable is regarded more important by older workers than by younger workers, i.e., "physically exhausting job" (mean rank $=70.9$ for older employees and 55.64 for young workers with $p=0.019$ ). 
Table 5. Psychosocial workforce diversity factors influencing the construction worker productivity.

\begin{tabular}{ccccccc}
\hline Variables & $\begin{array}{c}\text { Old } \\
\text { Mean Rank }\end{array}$ & $\begin{array}{c}\text { Young } \\
\text { Mean Rank }\end{array}$ & $p$ & $\begin{array}{c}\text { Experienced } \\
\text { Mean Rank }\end{array}$ & $\begin{array}{c}\text { Less } \\
\text { Experienced } \\
\text { Mean Rank }\end{array}$ & $p$ \\
\hline Uneven distribution of work & 61.11 & 73.52 & $0.061^{* *}$ & 62.64 & 68.83 & 0.330 \\
Relationships with coworkers & 63.82 & 68.57 & 0.447 & 67.03 & 63.72 & 0.580 \\
Daily task completion & 67.23 & 62.35 & 0.440 & 68.28 & 62.26 & 0.321 \\
Career advancement & 64.63 & 67.10 & 0.708 & 63.88 & 67.39 & 0.579 \\
Well-defined tasks & 63.32 & 69.49 & 0.346 & 66.74 & 64.05 & 0.669 \\
Physically exhausting job & 70.90 & 55.64 & $0.019 *$ & 66.96 & 63.80 & 0.612 \\
Team cooperation & 63.45 & 69.24 & 0.368 & 65.05 & 66.03 & 0.874 \\
Workplace satisfaction & 61.01 & 73.70 & $0.049^{*}$ & 65.14 & 65.92 & 0.900 \\
\hline Note. *
\end{tabular}

Note: ${ }^{*}$ significant at $0.01,{ }^{* *}$ significant at 0.05 .

Uneven distribution of work is always a problem for a firm or organization where there is a lack of management to utilize proper resources, whether in terms of human resources or machinery; younger employees are always the ones who seem to suffer under such circumstances [41]. Pakistan, since becoming independent, is still in a developing phase. The results show that younger employees do need to be overloaded with work as they are more energetic and enthusiastic, but uneven distribution is never accepted. Creating an inventory of all the work that must be done and then assigning tasks in step with every worker's specific function, position, and strengths is important. This exercise conjointly helps discover any gaps in talent.

Coming to the next variable, "workplace satisfaction", it is a natural fact that every person wants to do respectable work that he/she feels excited and comfortable to tell others about [69]. In the field of construction, younger employees are given enough responsibilities despite uneven distribution of work as discussed earlier that they feel happy to share about their job. In the past 5-8 years, the Pakistani government and the private sector have started many state-of-the-art projects, i.e., metro projects, Bahria Town, and a very recent Orange Line in Lahore, which have created a large space for employment. Numerous engagement surveys have tried to explain the behaviors regarding the workplace that makes workers happy in their jobs. The results found that work values also change as workers grow older [58,70]. Hence, it was concluded that provision of a satisfactory workplace has created a positive impact aside technical abilities in terms of productivity, including employee appreciation and recognition, organizational culture, autonomy, variety learning, and being challenged.

The third and important variable that is highlighted by older employees over younger employees is a "physically exhausting job". Construction is never a white-collar job. Job sites are not always situated in desirable locations with good weather conditions and altitudes, and distances always vary. Due to rapid increases in construction projects in Pakistan, the job demand for older employees has reached very high. Even if younger employees are capable enough to cope with the responsibilities, the experience of older employees can never be taken for granted. Such employees have and always will be in top priority when it comes to decision-making and supervision. In the field of construction, regardless of whether an employee is senior enough, he or she still has to visit distant sites, which might drain off their energies at an older age [44,58]. This can only be minimized by proving good packages and satisfactory job benefits so that older employees feel enthusiastic towards their work [33].

The fourth stage of the analysis was related to the technical skills-related diversity factors influencing the construction worker productivity. These factors were derived from a recent study based on the impact of skills on productivity [47]. The results obtained indicate two significant differences in terms of age and only one significant difference in terms of experience of workers regarding the technical skills-related workforce diversity factors' influence on the construction worker productivity, as shown in Table 6. 
Table 6. Technical skills-related workforce diversity factors influencing the construction worker productivity.

\begin{tabular}{|c|c|c|c|c|c|c|}
\hline Variables & $\begin{array}{l}\text { Old } \\
\text { Mean Rank }\end{array}$ & $\underset{\text { Mean Rank }}{\text { Young }}$ & $p$ & $\begin{array}{l}\text { Experienced } \\
\text { Mean Rank }\end{array}$ & $\begin{array}{c}\text { Less } \\
\text { Experienced } \\
\text { Mean Rank }\end{array}$ & $p$ \\
\hline Technical soundness & 62.40 & 71.16 & 0.126 & 65.52 & 65.48 & 0.993 \\
\hline Technical training & 67.01 & 62.74 & 0.477 & 63.89 & 67.38 & 0.546 \\
\hline Importance of vocational training & 64.24 & 67.79 & 0.583 & 63.38 & 67.98 & 0.459 \\
\hline Vocationally trained employees & 62.30 & 71.34 & 0.169 & 61.99 & 69.60 & 0.227 \\
\hline Regular interdepartmental trainings & 63.48 & 69.20 & 0.385 & 61.99 & 69.59 & 0.229 \\
\hline $\begin{array}{l}\text { High-technology equipment in the } \\
\text { Pakistani construction sector }\end{array}$ & 60.64 & 74.37 & $0.034^{* *}$ & 64.16 & 67.07 & 0.640 \\
\hline $\begin{array}{l}\text { Potential for skills, urban vs. rural } \\
\text { Impact of advancements in the }\end{array}$ & 65.47 & 65.55 & 0.990 & 58.31 & 73.88 & $0.015 * *$ \\
\hline $\begin{array}{l}\text { construction technology on the } \\
\text { skills of workers }\end{array}$ & 61.23 & 73.30 & $0.064^{* * *}$ & 62.71 & 68.75 & 0.334 \\
\hline
\end{tabular}

In terms of age, two variables are regarded as more important by young workers than by old workers, i.e., "high-technology equipment in the Pakistani construction sector" (mean rank $=74.37$ for younger employees and 60.64 for older employees with $p=0.034$ ) and "impact of advancements in the construction technology on the skills of workers" (mean rank $=73.3$ for younger employees and 61.23 for older employees with $p=0.064$ ).

Due to the recent growth of the construction industry of Pakistan, state-of-the-art projects have emerged through collaboration of the government and the private sector. Orange Line in Lahore, Centaurus Mall in Islamabad, Bahria Town, and Neelum Jhelum hydropower are quite prominent among them. Highly advanced technological equipment was used for excavations, pouring, concreting, paving, and in all other phases of construction. This has not only given the construction rapid progress, but also high technical experience to young Pakistani workers and employees as compared to past decades [71].

Coming to the other very important variable, the impact of advancements in the construction technology has weakened the skills of the workers. Change is never an easy thing to cope up with, as the younger employees emphasized, especially when it is related to technologies and skills. Pakistan is not an advanced country in terms of construction, though in the last decade it has seen progressive changes in this industry. The majority of the workers in this industry come from rural areas. Following the basic techniques of masonry, concreting, excavation and other related phases, Pakistani workers are not sufficiently familiar with the latest technologies [71]. Lacking the basic knowledge and skillsets for the use of such equipment, it was found that the majority of young Pakistani workers are resistant to such changes, making them insecure in terms of their job demand.

In terms of experience, only one variable is regarded more important by less experienced workers as compared to experienced workers, i.e., "potential for skills, urban vs. rural" (mean rank $=73.88$ for less experienced employees and 58.31 for experienced employees with $p=0.015$ ).

Pakistan has been going through its developing phase since becoming independent and is still far behind the world in terms of advancements in technology. There is a very prominent disparity between rural and urban areas here with respect to everything, e.g., food, health, lifestyle, culture, technology, and growth [72]. Old construction techniques are still being followed in the majority of the rural areas, including mud houses, pathways, open sewage, etc. The majority of the less experienced Pakistani employees come from rural areas. When these people come to urban areas for work, they are not very familiar with much of today's construction equipment that is in use. As they have not seen such equipment or built structures or pavements like the ones in urban areas before, they find it very difficult to learn how to use and operate such equipment [71].

\section{Conclusions}

The stream of the impact of workforce diversity has been examined from a few perspectives by few researchers. Some crosscutting themes on the diverse workforce factors affecting an employee's performance have been provided by the information about the 
types and roles of diversity in firms. Instead of relying on a sole approach to examine the phenomenon of diversity for Pakistani CCFs, an incorporated framework fetching the key theories on workforce diversity was utilized to gain insight. This research provides a novel insight into the worker productivity literature by showing how workforce diversity is associated with employees' age and experience.

The research analyzed a total of four groups of workforce diversity factors. All these factors were analyzed on the basis of age and experience of an employee, and we conclude that the highlighted factors have a very keen impact on the productivity of workers. The motivation was found to be the artery of a physical workforce. The equity theory of wages depicts that the standard driving force of the performance is motivation and passion. Income and other incentives were found to be of vital importance for younger employees. Job pressures do have an impact on psychosocial strains of young workers, but the main contributor to such strains is control of the employees over the demands they have to deal with, which reduces psychosocial stress. Moving forward, younger employees are found to be more satisfied with the responsibilities they have as compared to older employees. Both the young and the less experienced employees put emphasis on the scheduling of their tasks with less interference.

Conversely, the experienced workers complained about fewer advancement options as a demotivating factor for their careers. Furthermore, the results proposed that older experienced construction workers disliked being asked about the given tasks again and again. When it comes to the uneven distribution of tasks, young workers are found to be the most affected, which results in absenteeism and a negative correlation with the job. That in turn makes such workers reluctant to talk and share about their place of work. Rural areas should be provided with equipment and technologies for construction so that inexperienced rural workers could adapt to such equipment and become more resourceful for the industry.

The verdict of the research has administrative and managerial relevance, with several implications to be observed. The research contributes to worker productivity by showing how employees of varied ages and diverse industry experience are associated with intrinsic workforce diversity factors. This study will help firm owners to reduce the negative relationship of workers with their jobs. It provides insights for contractors and supervisors in Pakistani CCFs on the critical weaknesses associated with management of a well-organized, skillful, and diverse workforce with respect to age and experience of employees which need to be addressed and overcome while undertaking international standards for wages, incentives, opportunities for advancement, health, and sociocultural securities. Another important aspect derived from this research leads to a keen concern about laborers' demotivation, especially in the case of old and experienced workers, and burnout conditions in young workers. The Pakistani government and construction firms need to restructure their labor policies in order to tackle diversity and increase worker productivity.

Author Contributions: All authors contributed equally to this research. All authors have read and agreed to the published version of the manuscript.

Funding: This research was funded by Taif University Researchers Supporting Project (grant No. TURSP-2020/324).

Data Availability Statement: All the data are available within this manuscript.

Acknowledgments: The authors would like to acknowledge the finical support provided by Taif University Researchers Supporting Project (grant No. TURSP-2020/324).

Conflicts of Interest: The authors declare no conflict of interest. 


\section{References}

1. Podsiadlowski, A.D.; Gröschke, M.; Kogler, C.; Springer, C.; Van Der Zee, K. Managing a culturally diverse workforce: Diversity perspectives in organizations. Int. J. Intercult. Relat. 2013, 37, 159-175. [CrossRef]

2. Stahl, G.K.; Björkman, I.; Morris, S. Handbook of Research in International Human Resource Management; Edward Elgar Publishing: Cheltenham, UK, 2012.

3. McKay, P.F.; Avery, D.R.; Morris, M.A. A tale of two climates: Diversity climate from subordinates' and managers' perspectives and their role in store unit sales performance. Pers. Psychol. 2009, 62, 767-791. [CrossRef]

4. Jackson, S.E.; Joshi, A.; Erhardt, N.L. Recent research on team and organizational diversity: SWOT analysis and implications. J. Manag. 2003, 29, 801-830.

5. Roberge, M.-É; Van Dick, R. Recognizing the benefits of diversity: When and how does diversity increase group performance? Hum. Resour. Manag. Rev. 2010, 20, 295-308. [CrossRef]

6. Paoletti, J.; Gilberto, J.M.; Beier, M.E.; Salas, E. The role of aging, age diversity, and age heterogeneity within teams. In Current and Emerging Trends in Aging and Work; Springer: Berlin/Heidelberg, Germany, 2020; pp. 319-336.

7. Lauring, J.; Selmer, J. Multicultural organizations: Does a positive diversity climate promote performance? Eur. Manag. Rev. 2011, 8, 81-93. [CrossRef]

8. Guillaume, Y.R.; Dawson, J.F.; Otaye-Ebede, L.; Woods, S.A.; West, M.A. Harnessing demographic differences in organizations: What moderates the effects of workplace diversity? J. Organ. Behav. 2017, 38, 276-303. [CrossRef]

9. Downey, S.N.; van der Werff, L.; Thomas, K.M.; Plaut, V.C. The role of diversity practices and inclusion in promoting trust and employee engagement. J. Appl. Soc. Psychol. 2015, 45, 35-44. [CrossRef]

10. Jarkas, A.M. Critical investigation into the applicability of the learning curve theory to rebar fixing labor productivity. J. Constr. Eng. Manag. 2010, 136, 1279-1288. [CrossRef]

11. Musarat, M.A.; Alaloul, W.S.; Liew, M. Impact of inflation rate on construction projects budget: A review. Ain Shams Eng. J. 2020, 12, 407-414. [CrossRef]

12. Razzaq, A.; Thaheem, M.J.; Maqsoom, A.; Gabriel, H.F. Critical external risks in international joint ventures for construction industry in Pakistan. Int. J. Civ. Eng. 2018, 16, 189-205. [CrossRef]

13. Hur, Y.; Strickland, R.A. Diversity management practices and understanding their adoption: Examining local governments in North Carolina. Public Adm. Q. 2012, 36, 380-412.

14. Maqsoom, A.; Bajwa, S.; Zahoor, H.; Thaheem, M.J.; Dawood, M. Optimizing contractor's selection and bid evaluation process in construction industry: Client's perspective. Rev. Construcción 2019, 18, 445-458. [CrossRef]

15. Garnero, A.; Kampelmann, S.; Rycx, F. The heterogeneous effects of workforce diversity on productivity, wages, and profits. Ind. Relat. J. Econ. Soc. 2014, 53, 430-477. [CrossRef]

16. Maqsoom, A.; Ashraf, H.; Choudhry, R.M.; Khan, S.Y.; Dawood, M.; Tariq, A. Extrinsic factors influencing the bid/no-bid decision of construction contracting firms: Impact of firm size and experience. Rev. Construcción 2020, 19, 146-158. [CrossRef]

17. Alaloul, W.S.; Musarat, M.A.; Liew, M.; Qureshi, A.H.; Maqsoom, A. Investigating the impact of inflation on labour wages in Construction Industry of Malaysia. Ain Shams Eng. J. 2021, 12, 1575-1582. [CrossRef]

18. Ibrahim, M.; Brobbey, V.A. Impact of motivation on employee performance. Int. J. Econ. Commer. Manag. 2015, 3, $1218-1237$.

19. Van Dalen, H.P.; Henkens, K.; Schippers, J. Productivity of older workers: Perceptions of employers and employees. Popul. Dev. Rev. 2010, 36, 309-330. [CrossRef]

20. Alsuwaiyel, M.H. Algorithms: Design Techniques and Analysis (Revised Edition); World Scientific: Singapore, 2016 ; Volume 14.

21. Vandenberghe, V. Is workforce diversity good for efficiency? An approach based on the degree of concavity of the technology. Int. J. Manpow. 2016, 37, 253-267. [CrossRef]

22. Frosch, K.H. Workforce age and innovation: A literature survey. Int. J. Manag. Rev. 2011, 13, 414-430. [CrossRef]

23. Joshi, A.; Roh, H. Context matters: A multilevel framework forwork team diversity research. In Research in Personnel and Human Resources Management; Emerald Group Publishing Limited: Bingley, UK, 2007; pp. 1-48.

24. Quińones, M.A.; Ford, J.K.; Teachout, M.S. The relationship between work experience and job performance: A conceptual and meta-analytic review. Pers. Psychol. 1995, 48, 887-910. [CrossRef]

25. Karasek, R.A., Jr. Job demands, job decision latitude, and mental strain: Implications for job redesign. Adm. Sci. Q. 1979, 24, 285-308. [CrossRef]

26. Adams, J.S.; Hoffman, B. The frequency of self-reference statements as a function of generalized reinforcement. J. Abnorm. Soc. Psychol. 1960, 60, 384. [CrossRef] [PubMed]

27. Al-Bayati, A.J.; Abudayyeh, O.; Albert, A. Managing active cultural differences in US construction workplaces: Perspectives from non-Hispanic workers. J. Saf. Res. 2018, 66, 1-8. [CrossRef] [PubMed]

28. Al-Bayati, A.J.; Abudayyeh, O.; Fredericks, T.; Butt, S.E. Managing Cultural Diversity at US Construction Sites: Hispanic Workers' Perspectives. J. Constr. Eng. Manag. 2017, 143, 04017064. [CrossRef]

29. Mandell, B.; Kohlergray, S. Management development that values diversity. Personnel 1990, 67, 41-47.

30. Lauretta McLeod, P.; Lobel, S.A. The effects of ethnic diversity on idea generation in small groups. In Academy of Management Proceedings; Academy of Management Briarcliff Manor: New York, NY, USA, 1992; pp. 227-231.

31. Adler, N.J.; Gundersen, A. International Dimensions of Organizational Behavior; Cengage Learning: Boston, MA, USA, 2007. 
32. Bender, S.; Bloom, N.; Card, D.; van Reenen, J.; Wolter, S. Management practices, workforce selection, and productivity. J. Labor Econ. 2018, 36 (Suppl. S1), S371-S409. [CrossRef]

33. Bonhomme, S.; Hospido, L. The cycle of earnings inequality: Evidence from Spanish social security data. Econ. J. 2017, 127, 1244-1278. [CrossRef]

34. Jones, S.; Tarp, F. Priorities for Boosting Employment in Sub-Saharan Africa: Evidence for Mozambique. Afr. Dev. Rev. 2015, 27 (Suppl. S1), 56-70. [CrossRef]

35. Spies, M. Distance between home and workplace as a factor for job satisfaction in the North-West Russian oil industry. Fenn. Int J. Geogr. 2006, 184, 133-149.

36. Wegge, J.; Jeppesen, H.J.; Weber, W.G.; Pearce, C.L.; Silva, S.A.; Pundt, A.; Jonsson, T.; Wolf, S.; Wassenaar, C.L.; Unterrainer, C. Promoting work motivation in organizations. J. Pers. Psychol. 2011, 9, 154-171. [CrossRef]

37. Hofstede, G. Motivation, leadership, and organization: Do American theories apply abroad? Organ. Dyn. 1980, 9, 42-63. [CrossRef]

38. Funso, A.; Sammy, L.; Gerryshom, M. Impact of Motivation on Productivity of Craftsmen in Construction Firms in Lagos, Nigeria Int. J. Econ. Financ. 2016, 8, 271. [CrossRef]

39. Safdar, U.; Badir, Y.F.; Afsar, B. Who can I ask? How psychological safety affects knowledge sourcing among new product development team members. J. High Technol. Manag. Res. 2017, 28, 79-92. [CrossRef]

40. Kakui, I.M. Effects of Career Development on Employee Performance In the Public Sector: A Case of National Cereals and Produce Board. Strateg. J. Bus. Chang. Manag. 2016, 3, 307-324.

41. Eller, N.H.; Netterstrøm, B.; Gyntelberg, F.; Kristensen, T.S.; Nielsen, F.; Steptoe, A.; Theorell, T. Work-related psychosocial factors and the development of ischemic heart disease: A systematic review. Cardiol. Rev. 2009, 17, 83-97. [CrossRef]

42. Boyas, J.; Wind, L.H. Employment-based social capital, job stress, and employee burnout: A public child welfare employee structural model. Child. Youth Serv. Rev. 2010, 32, 380-388. [CrossRef]

43. Glazer, S.; Kruse, B. The role of organizational commitment in occupational stress models. Int. J. Stress Manag. 2008, 15, 329. [CrossRef]

44. Kazaz, A.; Ulubeyli, S. Drivers of productivity among construction workers: A study in a developing country. Build. Environ. 2007, 42, 2132-2140. [CrossRef]

45. Abdel-Wahab, M.S.; Dainty, A.R.; Ison, S.G.; Bowen, P.; Hazlehurst, G. Trends of skills and productivity in the UK construction industry. Eng. Constr. Archit. Manag. 2008, 15, 372-382. [CrossRef]

46. Rojas, E.M.; Aramvareekul, P. Labor productivity drivers and opportunities in the construction industry. J. Manag. Eng. 2003, 19, 78-82. [CrossRef]

47. Deming, D.J. The growing importance of social skills in the labor market. Q. J. Econ. 2017, 132, 1593-1640. [CrossRef]

48. Sambasivan, M.; Soon, Y.W. Causes and effects of delays in Malaysian construction industry. Int. J. Proj. Manag. 2007, 25, 517-526. [CrossRef]

49. Commission, E. New Skills for New Jobs: Action Now. A Report by the Expert Group on New Skills for New Jobs Prepared for the European Commission; European Commission: Brussels, Belgium, 2010.

50. Harrison, D.A.; Price, K.H.; Bell, M.P. Beyond relational demography: Time and the effects of surface-and deep-level diversity on work group cohesion. Acad. Manag. J. 1998, 41, 96-107.

51. Borst, R.T.; Kruyen, P.M.; Lako, C.J. Exploring the job demands-resources model of work engagement in government: Bringing in a psychological perspective. Rev. Public Pers. Adm. 2019, 39, 372-397. [CrossRef]

52. Al-Zawahreh, A.; Al-Madi, F. The utility of equity theory in enhancing organizational effectiveness. Eur. J. Econ. Financ. Adm. Sci. 2012, 46, 159-169.

53. Schriesheim, C.A.; Powers, K.J.; Scandura, T.A.; Gardiner, C.C.; Lankau, M.J. Improving construct measurement in management research: Comments and a quantitative approach for assessing the theoretical content adequacy of paper-and-pencil survey-type instruments. J. Manag. 1993, 19, 385-417. [CrossRef]

54. Haynes, A.B.; Weiser, T.G.; Berry, W.R.; Lipsitz, S.R.; Breizat, A.-H.S.; Dellinger, E.P.; Dziekan, G.; Herbosa, T.; Kibatala, P.L.; Lapitan, M.C.M. Changes in safety attitude and relationship to decreased postoperative morbidity and mortality following implementation of a checklist-based surgical safety intervention. BMJ Qual. Saf. 2011, 20, 102-107. [CrossRef]

55. Lindell, M.K.; Whitney, D.J. Accounting for common method variance in cross-sectional research designs. J. Appl. Psychol. 2001, 86,114 . [CrossRef]

56. Idrees, M.D.; Hafeez, M.; Kim, J.-Y. Workers' age and the impact of psychological factors on the perception of safety at construction sites. Sustainability 2017, 9, 745. [CrossRef]

57. Chung, J.; Park, J.; Cho, M.; Park, Y.; Kim, D.; Yang, D.; Yang, Y. A study on the relationships between age, work experience, cognition, and work ability in older employees working in heavy industry. J. Phys. Ther. Sci. 2015, 27, 155-157. [CrossRef]

58. Maqsoom, A.; Mughees, A.; Zahoor, H.; Nawaz, A.; Mazher, K.M. Extrinsic psychosocial stressors and workers' productivity: Impact of employee age and industry experience. Appl. Econ. 2019, 52, 2807-2820. [CrossRef]

59. Srour, F.J.; Srour, I.; Lattouf, M.G. A survey of absenteeism on construction sites. Int. J. Manpow. 2017, 38, 533-547. [CrossRef]

60. Nadeem, M.; Ahmad, N.; Abdullah, M.; Hamad, N. Impact of employee motivation on employee performance (A Case Study of Private firms: Multan District, Pakistan). Int. Lett. Soc. Humanist. Sci. (ILSHS) 2014, 25, 51-58. [CrossRef] 
61. Kapiszewski, A. Arab versus Asian migrant workers in the GCC countries. In South Asian Migration to Gulf Countries; Routledge: London, UK, 2017; pp. 66-90.

62. Maqsoom, A.; Charoenngam, C.; Awais, M. Internationalization process of Pakistani contractors: An exploratory study. In ICCREM 2013: Construction and Operation in the Context of Sustainability; 2013; pp. 59-72. Available online: https:/ / scholar.google.com/citations?view_op=view_citation\&hl=ja\&user=IYQk3foAAAAJ\&alert_preview_top_rm=2\& citation_for_view=IYQk3foAAAAJ:u5HHmVD_uO8C (accessed on 7 October 2021).

63. Sauermann, H.; Cohen, W.M. What makes them tick? Employee motives and firm innovation. Manag. Sci. 2010, 56, 2134-2153. [CrossRef]

64. Thomas, K.W.; Velthouse, B.A. Cognitive elements of empowerment: An "interpretive" model of intrinsic task motivation. Acad. Manag. Rev. 1990, 15, 666-681.

65. Kazaz, A.; Manisali, E.; Ulubeyli, S. Effect of basic motivational factors on construction workforce productivity in Turkey. J. Civ. Eng. Manag. 2008, 14, 95-106. [CrossRef]

66. Rego, A.; Simpson, A.V. The perceived impact of leaders' humility on team effectiveness: An empirical study. J. Bus. Ethics 2018, 148, 205-218. [CrossRef]

67. Maqsoom, A.; Mughees, A.; Safdar, U.; Afsar, B.; Ali Zeeshan, B.u. Intrinsic psychosocial stressors and construction worker productivity: Impact of employee age and industry experience. Econ. Res. Ekon. Istraživanja 2018, 31, 1880-1902. [CrossRef]

68. Whitman, D.S.; van Rooy, D.L.; Viswesvaran, C. Satisfaction, citizenship behaviors, and performance in work units: A metaanalysis of collective construct relations. Pers. Psychol. 2010, 63, 41-81. [CrossRef]

69. Helm, S. Employees' awareness of their impact on corporate reputation. J. Bus. Res. 2011, 64, 657-663. [CrossRef]

70. Wey Smola, K.; Sutton, C.D. Generational differences: Revisiting generational work values for the new millennium. J. Organ. Behav. Int. J. Ind. Occup. Organ. Psychol. Behav. 2002, 23, 363-382. [CrossRef]

71. Gardezi, S.S.S.; Manarvi, I.A.; Gardezi, S.J.S. Time extension factors in construction industry of Pakistan. Procedia Eng. 2014, 77, 196-204. [CrossRef]

72. Ellison, G.; Glaeser, E.L. The geographic concentration of industry: Does natural advantage explain agglomeration? Am. Econ. Rev. 1999, 89, 311-316. [CrossRef] 